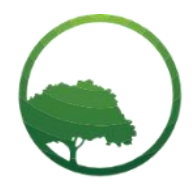

Research in Business \& Social Science

IJRBS VOL 10 NO 4 ISSN: 2147-4478

\title{
Examining the link between organizational citizenship behavior and work performance of employees in the private schools, mediated by workplace environment
}

\author{
(DD) Damianus Abun ${ }^{(a)}$ (iD) Gladys Jean Q. Basilio ${ }^{(b)}$ (D) Theogenia Magallanes ${ }^{(c)}$ \\ (D) Mary Joy Encarnacion ${ }^{(d)}$ (D) Micah Sallong ${ }^{(e)}$ \\ (a) Professor, College of Business Administration and Accountancy, Divine Word College of Laoag, Ilocos Norte, Philippines \\ ${ }^{(b)}$ Ph.D., Vice President for Academic Affairs, Divine Word College of Laoag, Ilocos Norte, Philippines \\ ${ }^{(c)}$ Ed.D., President, Saint Benedict College of the Northern Luzon, Ilocos Sur, Philippines \\ ${ }^{(d)}$ Ph.D., Program Head, Divine Word College of Vigan, Ilocos Sure, Philippines \\ ${ }^{(e)}$ MAEd: Dean, College of the Religious Education, St. Benedict College of the Northern Luzon, Ilocos Sur, Philippines
}

\begin{tabular}{l} 
A R T I C L E I N F O \\
\hline Article history: \\
Received 14 May 2021 \\
Received in rev. form 07 June 2021 \\
Accepted 09 June 2021 \\
Keywords: \\
Organizational citizenship behaviour, \\
work performance, work environment, \\
OCBO, OCBP \\
JEL Classification: \\
I21
\end{tabular}

I21

\begin{abstract}
A B S T R A C T
The study aimed to determine the organizational citizenship behaviour, work performance and work environment; the correlation between organizational citizenship behaviour and work performance; the correlation between work environment and organizational citizenship behaviour and work performance. Theories were discussed based on the literature and a conceptual framework was established. The study used the descriptive correlational research design and questionnaires were used to gather the data. The population of the study was all employees of the Divine Word Colleges in the Ilocos region, a total of 181 employees. The study found that organizational citizenship, the work performance of employees and the work environment is high and there is a significant correlation between organizational citizenship behaviour and work performance and there is a correlation between work environment and organizational citizenship behaviour and work performance. Therefore, the hypothesis of the study is accepted.
\end{abstract}

(C) 2021 by the authors. Licensee SSBFNET, Istanbul, Turkey. This article is an open access article distributed under the terms and conditions of the Creative Commons Attribution (CC BY) license (http://creativecommons.org/licenses/by/4.0/).

\section{Introduction}

Looking for better management to improve employees 'work performance is the concern of every manager. There are no single solutions to managing employees' work performance because there are a lot of factors that affect employees' work performance, either they are tangible or intangible. One of the areas that have not been explored much is the effect of organizational citizenship behaviour on the work performance of employees.

There have been few studies related to the effect of organizational citizenship behaviour on performance such as the study of Mackenzie, et.al. (1993) on the effect of organizational citizenship and sales performance, Titisari (2016) on the role of organizational citizenship behaviour in improving work engagement of employees, Hasani and Sheikhesmaeili (2013) on the effect of organizational citizenship behaviour and organizational commitment, Firmansyah, et.al. (2014) on the role of organizational citizenship behaviour in improving total quality management (TQM). These studies have shown the effect of organizational citizenship behaviour on performance and the performance that is being measured is a single construct.

Work performance is not a single construct but multiple constructs which includes task performance, contextual performance, and counterproductive behaviour (Koopmans, et.al (2014). Related to this new concept, there have been no studies yet conducted

* Corresponding author. ORCID ID: 0000-0002-9693-1541

(C) 2021 by the authors. Hosting by SSBFNET. Peer review under responsibility of Center for Strategic Studies in Business and Finance.

https://doi.org/10.20525/ijrbs.v10i4.1229 
concerning the effect of organizational citizenship behaviour on the work performance of employees in the private school setting. Organizational citizenship refers to the behaviour of organization members that goes beyond task performance as required by their job description (Borman, 2004). These are positive behaviours that are being self-motivated but positively helping the organization. Their behaviour helps improve the organizational, social and psychological environment of the organization in which members can work happily (Borman, 2004).

There have been studies related to the effect of organizational citizenship behaviour and sales unit and team effectiveness (Posdakoff \& Mackenzie, 1994, Miao \& Kim, 2009), and job satisfaction (Welkamp \& Goritz, 2016) but there have been no studies related to the effect of organizational citizenship behaviour toward the three dimensions of work performance.

The current study focuses on the organizational citizenship behaviour of employees of private schools and the work performance within the three components of work performance such as task, contextual performance, and counterproductive behaviour. The study is born out of concern of work realities. Employees come on time and go home on time and seldom seeing employees stay beyond office hours and seldom see employees perform voluntary behaviour. To prevent further escalation of compliance behaviour, it is important to introduce new behaviour that is necessary for organizational development. The businesses have been in constant competition and winning the competition is not only about updating technological-know-how and other skills but it is also about the behaviour of employees who perform the work. The competition is not only faced by business industries but it is also faced by educational industries.

Education has been in competition in terms of its quality and enhancing education quality is not only about acquiring the state of the art technology and skills but it is also about proper behaviour. The behaviour can affect the effectiveness and performance of an organization (Ocampo, et.al. 2018). Thus, the purpose of this study is to determine their organizational citizenship behaviour and find ways or strategies on how to improve organizational citizenship behaviour.

This study intends to determine the relationship between organizational citizenship behaviour and individual work performance and the influence of work environment on organizational citizenship behaviour and work performance. It specifically seeks to answer the questions:

i. What is the organizational citizenship behaviour of employees in terms of

a. OCBO

b. OCBP

ii. What is the work performance of employees in terms of

a. Task performance

b. Contextual performance

c. Counterproductive work behaviour

iii. What is the work environment of the Divine Word Colleges in terms of

a. Hedonic environment

b. Eudaimonic environment

iv. Is there a relationship between organizational citizenship behaviour and work performance?

v. Is there a relationship between work environment and organizational citizenship and work performance?

The study assumes that organizational citizenship behaviour affects the work performance of employees but the effect on both, organizational citizenship and work performance are mediated by the work environment. The study is conducted in Divine Word College of Laoag and Divine Word College of Vigan. Both schools are located in two provinces which is Ilocos Norte and Ilocos Sur. It delimits its discussion and investigation on the organizational citizenship behaviour of employees of the two colleges and their work performance which are task performance, contextual performance, counterproductive behaviour, and work environment which include hedonic and eudaimonic work environment.

The study is divided into five parts. The first part is the introduction which explains the rationale of the study. The second part is the review of related literature. This part tries to find some related literature that is related to the current investigation to strengthen the theory of the current study and to find the gaps from previous studies and to be pursued by the current study. The third part is the research methodology that presents the research design, the population, the research instruments, the data gathering procedures, the locale of the study, and the statistical treatment of data. The fourth part is the data presentation and analysis in which the data gathered through questionnaires are presented and interpreted. The fifth part is the result and discussion which discusses the further result of the study and its implication and its conclusion.

\section{Literature Review}

The purpose of the literature review is to find more discussions of the current topic for the researcher to have more ideas about what he/she is going to investigate and establish a theoretical foundation of the current study. In other words, through a literature review, the researcher situates his/her work within the existing knowledge (McCombes, 2021). Based on the literature review, the theories and conceptual framework of the study is established. 


\section{Theoretical and Conceptual Frameworks}

\section{Organizational Citizenship Behavior}

Based on the literature review, the concept of organizational citizenship behaviour was already introduced in the 1930s but it was only officially defined in the 1980s. Since then the organizational citizenship becomes the subject of investigation of many researchers (Ocampo, et.al. 2018). Organizational citizenship refers to the behaviour of employees that are not originated from their job description as provided by the management but these are voluntary behaviour that helps promote and improve the organizational, social and psychological environment which is an important factor to help people perform their task and deliver the output (Borman, 2004). This concept implies that the behaviour that is being performed may not be related to the task performance but it may also be related to another kind of job within the organization and may affect positively other jobs or other people in the organization. Organizational citizenship behaviour is often referring to all kinds of constructive and positive behaviours which are born out of their free will (AIHR Digital, 2020). These kinds of behaviour are considered personal characteristics and personal commitment of employee and since it is a personal characteristic and personal commitment, thus not all employees possess the same behaviour (Newland, 2012). These behaviours are often related to discretionary or non-required behaviour of employees that help the organization and it is also argued that organizational citizenship behaviour is associated with certain personality (Organ, 2015). In other studies, instead of calling it organizational citizenship behaviour, but it is called personal initiative (Frese \& Fay, 2001). It is considered as self-starting and proactive behaviour to help the organization. Frese and Fay (2001) contended that this is the future work behaviour that is needed by the organization.

Since organizational citizenship behaviour is important for organizational success, then the management needs to find out the reason why people or employees are engaging in organizational citizenship behaviour. Newland (2012) as cited from George and Brief (1992) pointed out one of the main causes is job satisfaction. George and Brief (1992) argued that when employees are satisfied with their job, there is a desire to do more to help the organization. The second factor that may affect organizational citizenship behaviour is perceived fairness (Adams, 1965). This finding suggests that when the employees are treated fairly and recognized based on their inputs, the more employees are engaging in organizational citizenship behaviour, and the more motivated employees become to do more for the organization. The third factor that can cause organizational citizenship behaviour is person-organization fit (Netemeyer, et.al. 1997). When there is a perfect match between the characteristics of the person and the organization where she/he is working would affect job satisfaction and job satisfaction would promote other voluntary behaviour to help the organization.

Originally organization citizenship behaviour was classified into two dimensions only such as altruism and compliance (Bateman \& Organ, 1983) but later, Organ (1988) classified it again into five dimensions such as conscientiousness which refers to the behaviour that may benefit the whole organization, sportsmanship that reflects employees' willingness to deal with the problems of the organization without complaining, and have courtesy that explains the behaviour of employees who are willing to share information with other co-employees to prevent further problems that may damage the organization and the work of co-employees, civic virtue which defines employees are not absent in every activity of the organization such as meetings and helping behaviour which refers to the behaviour of employees who are willing to help other employees who are encountering problems with their new task or assignment.

Concerning the underlying motive of organizational citizenship behaviour may vary from one person to another but the common denomination among different motives are altruistic behaviour and pro-social values (Rioux \& Penner, 2001, Lemmon \& Wayne, 2014). Their studies suggest that employees who are altruistic by nature and possess pro-social values are inclined to perform behaviours that are helping other people and the organization. Since it is intrinsically motivated behaviour, therefore these behaviours are performed not for reward but purely for the good of the organization (Hazzi, 2018). Since these behaviours are intrinsically motivated, therefore they are not enforceable by the organization (Bergeron, 2007), and enforcing them might not help the behaviour to develop.

\section{The Importance of Supportive Work Environment for OCB}

Studies have been conducted to determine the effect of organizational citizenship and the performance of an organization. Yaakobi and Weisberg (2020) studied the effect of organizational citizenship behaviour toward quality, creativity, and efficiency performance. Their study confirms the assumption that organizational citizenship influences performance as a whole in terms of quality, creativity, and efficiency. Organizational citizenship behaviour is needed by all kinds of industries including hospitals. For example, Basu, et.al., (2017) studied the effect of organizational citizenship behaviour of healthcare workers on their performance and their study found a similar result that organizational citizenship behaviour affects the performance of healthcare workers in the hospitals. These findings are also confirmed by the study of Nielsen, et.al. (2009).

Given those findings, one should understand that organizational citizenship behaviour is also dependent on many factors. One of those factors is the workplace environment. Even though organizational citizenship is intrinsically motivated, however, such motivation may be hampered by a workplace environment as has been posited by other researchers. The behaviour of employees is also influenced by the environment where they are in. Garg, et.al. (2015) in their study found that the work environment cultivates worthwhile behaviour in which they identified organizational justice enhances psychological well-being of employees which consequently influences organizational citizenship behaviour. This is related to what George and Brief (1992) pointed out the job 
satisfaction cultivates organizational citizenship behaviour and also fairness is considered to be one of the factors to influence organizational citizenship behaviour (Adams, 1965). When the organization care for the well-being of employees, the employees may exert more extra effort to help the organization. Beyond that, the person-organization fit may contribute to voluntary behaviour (Netemeyer, et.al. 1997). LePine, et.al. (2018) pointed out the importance of a positive social and psychological environment in which tasks can flourish and for the individual to be effective. In short, a supportive work environment refers to what Lomas, (2019), Fleurbaey and Blanchet (2013), and Reeves, (2019) had argued that is a multidimensional construct that includes physical health, emotional, psychological, and mental well-being that employees experience in the workplace. Van Horn et.al. (2004) identified two dimensions of workplace well-being which are called hedonic and eudemonic well-being. Hedonic workplace well-being refers to a comfortable workplace, while eudemonic well-being is concerning with the realization of employees' autonomy, relatedness, and competence needs. These needs are considered intrinsic motivation and according to Baard, e.al. (2006) that these needs must be fulfilled to attain workplace well-being and performance.

The different workplace has different work environments and its role cannot be ignored in terms of its influence on the work behaviour of employees. This is a particular concern of the current study and the reason why the current study focuses on the school work environment and its role in promoting positive work behaviour of employees. This was proven by the study of Caroline, et.al. (2019) on the role of work environment, type of school and teachers' performance and this study found a correlation between positive school work environment and work performance of teachers in Nigeria. The study of Brown and Leigh (1996) supports such a finding that employees' perception of the organizational environment affects positive behaviour and organizational performance.

\section{Work Performance}

Work performance has been the main concern of every management and whatever kind of industry. This is an issue and concern all over the world that motivate researchers to find out factors that affect performance and how to manage high performance (Koopmans, et.al. 2011). The output of these researches is expected to help managers to find the answers or solution on how to make an employee productive as much as possible (Koopmans, et.al. 2011). It is a fact that low and high performance are two sides of the organizational realities that should be given attention because it affects the organization as a whole and determines its survival. The objective of management is how to motivate employees to achieve high performance. This is because high individual work performance practices determine organizational performance (Combs, et.al. 2006). Therefore, the key in solving organizational performance is individual employee performance. Individual work performance is not defined in terms of productivity or the quality of the output but it is the behaviours of individual employees that are supportive of organizational goals (Campbell, 1990). This definition does not refer to the objective measures of work performance but all kinds of behaviours that may or may not help the organization. A manager has to identify different behaviours that will support performance. This is of crucial importance because having a clear concept about work performance helps the manager to identify specific problems of individual performance. In other words, the manager needs to know the components of work performance and knowing these components help the manager to pinpoint the problem. Problems are either caused by the tasks themselves, or the context, or the counterproductive behaviours.

The existence and performance of any organization, depending on employees' work performance and thus, has to be understood, and defined by those who manage the organization. Why so? It is because individual performance problems is not a single construct after all but it is a multidimensional construct. A manager needs to understand what particular individual performance is. In other words, the manager must know what constitutes individual performance. Without a clear understanding of what constitutes individual work performance is, is often time the source of problem or difficulties in measuring work performance (Stewart \& Walsh, 2009). It is acknowledged that measuring individual work performance has been confusing because different jobs have a different construct of what it constitutes and consequently, researchers or organizations have come out with different measures of individual work performance (Koopmans, et.al. 2011). Many performance assessments are constructed only to measure individual work performance in terms of the quantity productivity or output and quality which is used by Renn and Fedor (2001). Using this kind of evaluation, employees' performance is only measured based on how much/many he/she produced and how good it is. This kind of evaluation has been criticized because it does not reflect the complexities of different work behaviours that constitute individual work performance (Campbell, 1990, Griffin, 1993).

Later research (Koopmans, et.al. 2011) suggests that individual work performance has three components and they are task performance, contextual performance, and counterproductive behaviour (Koopmans, et.al., 2011, Campbell, 1990, Griffin, et.al, 1993, Fay \& Sonentag, 2010). Task performance is considered the most important dimension of individual work performance because task performance facilitates someone to carry out one's duties and responsibilities. It refers to task proficiency or competency that someone has to perform the job. Task proficiency or competency includes job knowledge, and skills (technical proficiency) (Griffin, et.al., 2007, Wisecarver, 2007, Campbell, 1990, Rollins \& Fruge, 1992). These elements are essential to the performance of a task. Another dimension of task performance is contextual performance. The concept of contextual performance has nothing to do with technical skills or job knowledge because it refers to specific behaviours that are supportive of the work environment. It has been defined as "individual behaviours that support the organizational, social, and psychological environment in which the technical core must function" (Borman \& Motowidlo, 1993). Other researchers call this dimension organizational citizenship behaviour such as Viswesvaran and Ones (2000), Rotundo and Sackett (2002), and Allen (2008) and these behaviours may include taking on extra jobs that are not related to the job description that may help the organization. Lastly is counterproductive behaviour. This refers to behaviours that may harm the well-being of the organization (Koopmans, et.al. 2011). These behaviours may include absenteeism, 
coming late and leaving early from the office, doing some businesses that are not related to the job, theft, destroying the assets or properties of the organization, etc. Other researcher calls it hazardous behaviour (Murphy, 1989) which lead to the damage of the organization.

\section{Conceptual Framework}

Independent Variable

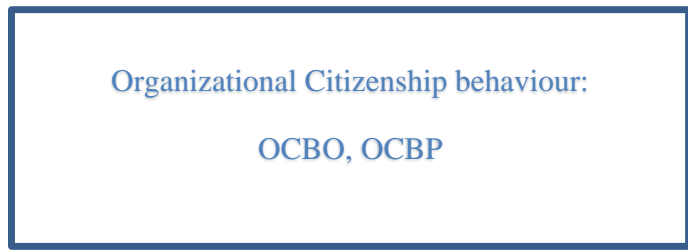

\section{Dependent Variable}

Work Performance:

Task Performance, Contextual performance, Counterproductive Behaviour

Work Environment: Hedonic and Eudemonic Work

Environment

Figure 1: The conceptual framework reflects the correlation between organizational citizenship behaviour and work performance. However, both, organizational citizenship behaviour and work performance can be affected by the work environment; Source: Spector (n.d) and Koopmans, et.al. (2011), National Library of Medicine (2020)

\section{Hypothesis}

Since the study is to measure the effect of organizational citizenship behaviour toward work performance which is mediated by the work environment, therefore, the following hypothesis is proposed:

Hypothesis 1: There is a significant relationship between organizational citizenship behaviour and work performance.

Hypothesis 2: There is a significant relationship between work environment and organizational citizenship behaviour

Hypothesis 3: There is a significant relationship between work environment and work performance.

\section{Research and Methodology}

Scientific research requires a scientific method of investigation. It follows the prescribed methodology to conduct its investigation. Research methodology is an established process for conducting the inquiry. It applies certain methods to determine, select, and analyze the data related to the concerned topic (Wilkinson, 2000, Leedy, 1974). Therefore the current study applies certain methods of investigation such as research design, data gathering instruments method, the population of the study, the locale of the study, data gathering procedures, and the statistical treatment of data.

\section{Research Design of the study}

The research design of the study is the descriptive assessment and descriptive correlational research design. Ariola (2006) argued that a descriptive correlation study is intended to describe the relationship among variables without seeking to establish a causal connection. While descriptive research is simply to describe a population, a situation, or a phenomenon. It is also used to describe profiles, frequency distribution, describe characteristics of people, situations, or phenomena. In short, it answers the question of what, when, how, where, and not why question (McCombes, 2020).

\section{The locale of the Study}

The locale of the study was Divine Word Colleges namely Divine Word College of Laoag and Divine Word College of Vigan. These two colleges are located in Vigan City, the heritage city of Ilocos Sur, and Laoag City, the capital of Ilocos Norte.

\section{Population}

The respondents of the study are the employees of these colleges. Since the number of employees is limited, therefore, the total enumeration sampling was used and thus all faculty and employees from the two colleges were taken as respondents of the study. 


\section{Data Gathering instruments}

The study adopted validated questionnaires of Koopmans, et.al. (2011) on work performance, Czerw (2019) in a Diagnosing work engagement particularly on - Hedonic work environment and of Fox, Ryan, and Deci (2000) on the eudaimonic workplace environment. While concerning organizational citizenship behaviour, the questionnaires of Specter (n.d) from Pennsylvania University and Chiun Lo and Ramayah (2009) were adopted. The questionnaires that are taken from Fox and Specter (n.d) are only those that are related to measuring the acts to help co-workers with job-related and the acts that are helping the organization which is classified as OCBO and OCBP.

\section{Data Gathering Procedures}

To preserve the integrity of scientific research, the data were gathered after the approval of the Presidents of different colleges. The researcher sent a letter to the president and after the letters were approved, the questionnaires were distributed by the researcher's representative. Then the researcher's representative from each institution collected the data and submitted it to the researcher for tabulation.

\section{Ethical Procedures}

The study was carried out after the research ethics committee examined and approved the content of the paper if it does not violate ethical standards and if it does not cause harm to human life and the environment.

\section{Statistical Treatment of Data}

To analyze the data, a descriptive and inferential statistic was used. The weighted mean was used to determine the level of organizational citizenship behaviour of employees, work performance, and work environment, and the Pearson $r$ was used to measure the correlation between organizational citizenship behaviour and work performance of employees and the relationship between work environment and organizational citizenship and work performance.

The following ranges of values with their descriptive interpretation will be used:

$\begin{array}{ll}\text { Statistical Range } & \text { Descriptive Interpretation } \\ 4.21-5.00 & \text { strongly agree/Very High } \\ 3.41-4.20 & \text { Agree/High } \\ 2.61-3.40 & \text { somewhat agree/Moderate } \\ 1.81-2.60 & \text { Disagree/Low } \\ 1.00-1.80 & \text { Strongly disagree/Very Low }\end{array}$

\section{Data Presentation and Interpretation}

As a scientific and quantitative study, it should follow the rigid process of investigation through following research methodology and one of the requirements is the data gathering instruments. In this regard, the data were gathered through research questionnaires and have been tabulated and analysed statistically using weighted mean and Pearson $r$ correlation. Thus, in this part, the study presents its data and interpreted it. The presentation follows the structure of the statement of the problems and therefore, the data presentation answers all questions stated in the statement of the problems.

Problem 1: What is the organizational citizenship behaviour of employees in terms of OCBO and OCBP?

Table 1: The Organizational Citizenship Behavior of Employees as to OCBO

\begin{tabular}{lcc}
\hline A. OCBO: Acts that direct toward the organization & Mean & DR \\
\hline 1. Help new employees get oriented to the job. & 3.77 & $\mathrm{~A}$ \\
\hline 2. Offered suggestions to improve how work is done. & 3.76 & $\mathrm{~A}$ \\
\hline 3. Volunteered for extra work assignments. & 3.73 & $\mathrm{~A}$ \\
\hline 4. Said good things about your employer in front of others. & 3.74 & $\mathrm{~A}$ \\
\hline 5. Said good things about your school in the community outside the school. & 3.80 \\
\hline 6. Give up meals and other breaks to complete the work. & 3.65 \\
\hline 7. Offered suggestions for improving the work environment. & $\mathrm{A}$ \\
\hline 8. came in early or stay late without pay to complete a project or task. & $\mathrm{A}$ \\
\hline 9. Volunteer to share new job knowledge or skills with other employees. & 3.75 \\
\hline Composite mean & 3.65 \\
\hline Source: Specter & $\mathrm{A}$ \\
\hline
\end{tabular}

Source: Specter (n.d) and Chiun Lo and Ramayah (2009)

Based on the data presented in the table, it reveals that as a whole, the organizational citizenship behaviour of the employees in terms of OCBO (organizational citizenship behaviour for helping the organization) gained a composite mean of 3.73 which is described as "agree/high". This result demonstrates that as a whole the organizational citizenship behaviour of employees as to the OCBO is not 
very high and it is also not very low, low or moderate but it is high. In this regard, the employees agree to a certain extent that they have been performing behaviours that are helping the organization. Even if the items are taken separately, it shows that all items were rated with the same mean range level with the interpretation of "agree/high" such as "helping new employees get oriented to the job (3.77), offering suggestions to improve how work is done (3.76), volunteering for extra work assignments (3.73), saying good things about the employer in front of others (3.74), saying good things about the school in the community outside the school (3.80), giving up meals and breaks to complete the work (3.65), offering suggestions for improving the work environment (3.76), coming in early or stay late without pay to complete a project or task (3.75), and volunteering to share new job knowledge or skills with other employees" (3.65).

Table 2: The Organizational Citizenship Behavior of Employees as to OCBP

\begin{tabular}{llc}
\hline B. OCBP: Acts that are directed toward a person & Mean & DR \\
\hline 1. Lent a compassionate ear when someone had a work problem & 3.76 & $\mathrm{~A}$ \\
\hline 2. Lent a compassionate ear when someone had a personal problem. & 3.70 & $\mathrm{~A}$ \\
\hline 3. Change vacation schedule, workdays, or shifts to accommodate co-workers' needs. & 3.74 & $\mathrm{~A}$ \\
\hline 4. Help a less capable co-worker lift a heavy box or other objects & 3.76 & $\mathrm{~A}$ \\
\hline 5. Went out of the way to give co-worker encouragement or express appreciation. & 3.77 & $\mathrm{~A}$ \\
\hline $\begin{array}{l}\text { 6. Defended co-worker who was being 'put down" or spoken ill by other co-workers or } \\
\text { supervisors. }\end{array}$ & 3.70 & $\mathrm{~A}$ \\
\hline 7. Help co-workers with personal matters such as sharing food or drinks. & 3.76 & $\mathrm{~A}$ \\
\hline 8. Lent money or personal property to a co-worker. & 3.62 & $\mathrm{~A}$ \\
\hline Composite mean & $\mathbf{3 . 7 3}$ & $\mathrm{A}$ \\
\hline
\end{tabular}

Source: Specter (n.d) and Chiun Lo and Ramayah (2009)

Following the OCBO is the OCBP (organizational citizenship behaviour for helping other persons). As gleaned from the data, it displays that as a whole, organizational citizenship behaviour of employees in terms of OCBP obtained a composite mean of 3.73 which is interpreted as "agree/high". This result indicates that as a whole the organizational citizenship of employees related to helping other employees or co-workers is not very high and it is also not very low, low or moderate but it is high. The employees agree to a certain extent that they also perform behaviours that help other employees to be able to perform their works. Even when the items are taken singly, all items were evaluated within the same level mean range with the interpretation of "agree/high" such as "lending a compassionate ear when someone had a work problem (3.76), lending a compassionate ear when someone had a personal problem (3.70), changing vacation schedule, workdays, or shifts to accommodate co-workers' needs (3.74), helping a less capable co-worker lift a heavy box or other objects (3.76), going out of the way to give co-worker encouragement or express appreciation (3.77), defending co-worker who was being "put down" or spoken ill by other co-workers or supervisors (3.70), helping co-workers with personal matters such as sharing food or drinks (3.76), and lending money or personal property to a co-worker” (3.62).

Problem 2: What is the work performance of employees in terms of Task performance, Contextual performance and Counterproductive work behaviour?

Table 3: Individual Work Performance as to Task Performance

\begin{tabular}{lll}
\hline a. Task Performance (TP) & Mean & DR \\
\hline 1. I manage to plan my work so that it was done on time. & 3.82 & $\mathrm{~A}$ \\
\hline 2. My planning was optimal. & 3.79 & $\mathrm{~A}$ \\
\hline 3. I kept in mind the results that I have to achieve in my work. & 3.81 & $\mathrm{~A}$ \\
\hline 4. I was able to separate main issues from side issues at work. & 3.78 & $\mathrm{~A}$ \\
\hline 5. I knew how to set the right priorities. & 3.86 & $\mathrm{~A}$ \\
\hline 6. I was able to perform my work well with minimal time and effort. & 3.82 & $\mathrm{~A}$ \\
\hline Composite mean & $\mathbf{3 . 8 1}$ & $\mathbf{A}$ \\
\hline
\end{tabular}

Source: Koopmans, et.al. (2011)

As shown by the data in table 3 , it appears that as a whole the individual work performance of employees concerning task performance obtained a composite mean of 3.81 which is described as "agree/high". This composite mean indicates that as a whole the individual work performance of employees as to the task performance is not very high and it is also not very low, low or moderate but it is high. This result suggests that the employees agree that they perform their task to a high extent, though it is not very high. Even when the items are taken separately, all the items related to task performance are evaluated within the same level mean range with the interpretation of "agree/high" such as "managing to plan the work so that it was done on time (3.82), planning was optimal (3.79), keeping in mind the results to be achieved in the work (3.81), being able to separate main issues from side issues at work (3.78), knowing how to set the right priorities (3.86), and being able to perform the work well with minimal time and effort" (3.82). 
Table 4: Individual Work Performance as to Contextual Performance

\begin{tabular}{lll}
\hline b. Contextual Performance (CP) & Mean & DR \\
\hline 1. I took on extra responsibilities. & 3.82 & $\mathrm{~A}$ \\
\hline 2. I started a new task myself when my old ones were finished. & 3.82 & $\mathrm{~A}$ \\
\hline 3. I took on a challenging work task, when available. & 3.80 & $\mathrm{~A}$ \\
\hline 4. I worked at keeping my job knowledge up-to-date. & 3.76 & $\mathrm{~A}$ \\
\hline 5. I worked at keeping my job skills up-to-date. & 3.81 & $\mathrm{~A}$ \\
\hline 6. I came up with creative solutions to new problems. & 3.78 & $\mathrm{~A}$ \\
\hline 7. I kept looking for new challenges in my job. & 3.75 & $\mathrm{~A}$ \\
\hline 8. I did more than was expected of me. & 3.75 & $\mathrm{~A}$ \\
\hline 9. I actively participated in work meetings. & 3.82 & $\mathrm{~A}$ \\
\hline 10. I actively look for ways to improve my performance at work. & 3.82 & $\mathrm{~A}$ \\
\hline 11. I grasped opportunities when they presented themselves. & 3.77 & $\mathrm{~A}$ \\
\hline 12. I knew how to solve difficult situations and setbacks quickly. & 3.71 & $\mathrm{~A}$ \\
\hline Composite mean & $\mathbf{3 . 7 9}$ & $\mathbf{A}$ \\
\hline
\end{tabular}

Source: Koopmans, et.al. (2011)

Following the individual task performance is the contextual performance. As displayed by the data on the table, it portrays that as a whole, the work performance of employees as to the contextual performance obtained a composite mean of 3.79 which is understood as "agree/high". This composite mean rating suggests that as a whole employees' performance in terms of contextual performance is not very high and it is also not very low, low or moderate but it is high. This result means that the employees agree that they perform certain behaviours or other tasks that are not required of them but it is important to improve their work and make the work environment better. They were able to create a positive work environment that supports the performance of their tasks. Even if the items are taken independently, all items were assessed within the same level of mean range with the interpretation of " agree/high" such as "taking on extra responsibilities (3.82), starting a new task when the old ones were finished (3.82), taking on a challenging work task, when available (3.80), working at keeping my job knowledge up-to-date (3.81), coming up with creative solutions to new problems (3.78), keeping looking for new challenges in the job (3.75), doing more than was expected of (3.75), actively participating in work meetings (3.82), actively looking for ways to improve performance at work (3.82), grasping opportunities when they presented themselves (3.77), and knowing how to solve difficult situations and setbacks quickly" (3.71).

Table 5: Individual Work Performance as to Counterproductive Work Behaviour

\begin{tabular}{lll}
\hline c. Counterproductive work behaviour (CWB) & Mean & DR \\
\hline 1. I complained about unimportant matters at work. & 3.01 & SWA \\
\hline 2. I made problems greater than they were at work. & 2.95 & SWA \\
\hline 3. I focused on the negative aspects of a work situation, instead of on the positive aspects & 2.91 & SWA \\
\hline 4. I spoke with colleagues about the negative aspects of my work. & 3.03 & SWA \\
\hline 5. I spoke with people from outside the organization about the negative aspects of my work. & 2.85 & SWA \\
\hline 6. I did less than was expected of me. & 2.85 & SWA \\
\hline 7. I managed to get off from a work task easily. & 3.02 & SWA \\
\hline 8. I sometimes did nothing, while I should have been working. & 2.91 & SWA \\
\hline Composite mean & $\mathbf{2 . 9 4}$ & SWA \\
\hline
\end{tabular}

Source: Koopmans, et.al. (2011)

The last part of work performance is counterproductive to work behaviour. As pointed out by the data in the table, it manifests that as a whole, the work performance of employees concerning their counterproductive behaviour received a composite mean of 2.94 which is described as "somewhat agree/moderate". Such a result pointed out that the employees' counterproductive behaviour is not very high or high and it is also not very low, or low but it is moderate. This indicates that employees somewhat agree that they also perform counterproductive behaviours. In other words, though they agree that they perform their tasks and other works that may improve their work better, however, they admitted that they also did something that are not helpful to their work and the organization. Even when the items are taken separately, all items were evaluated within the same level mean range with the interpretation of "agree/high" such as "complaining about unimportant matters at work (3.01), making problems greater than they were at work (2.95), focusing on the negative aspects of a work situation, instead of on the positive aspects (2.91), speaking with colleagues about the negative aspects of my work (3.03), speaking with people from outside the organization about the negative aspects of the work (2.85), doing less than was expected of (2.85), managing to get off from a work task easily (3.02), and sometimes doing nothing, while I should have been working" (2.91). 
Problem 3: What is the work environment of the Divine Word Colleges in terms of Hedonic environment and Eudemonic environment?

Table 6: Workplace Environment as to Hedonic Environment

\begin{tabular}{lcc}
\hline A. Hedonic Environment & Mean & DR \\
\hline 1. Thanks to the institution, the institution provides enough benefits. & 3.50 & $\mathrm{~A}$ \\
\hline 2. I think that the work I am doing is interesting. & 3.73 & $\mathrm{~A}$ \\
\hline 3. The transparency of rules in my institution is making my work easier. & 3.55 & $\mathrm{~A}$ \\
\hline 4. I believe that the position in which I work is adequate for my skills. & 3.67 & $\mathrm{~A}$ \\
\hline 5. I seldom encounter problems in my work. & 3.52 & $\mathrm{~A}$ \\
\hline 6. I feel satisfied with my work. & 3.71 & $\mathrm{~A}$ \\
\hline 7. I feel that the atmosphere at my work is welcoming and friendly. & 3.64 & $\mathrm{~A}$ \\
\hline 8. My company is a positive workplace. & 3.56 & $\mathrm{~A}$ \\
\hline 9. I believe I am liked and accepted at work. & 3.67 & $\mathrm{~A}$ \\
\hline 10. I feel that my supervisors appreciate my work. & 3.70 & $\mathrm{~A}$ \\
\hline Composite mean & $\mathbf{3 . 6 3}$ & $\mathbf{A}$ \\
\hline
\end{tabular}

Source: Czerw (2019

As indicated by the data in table 6, it portrays that as a whole, workplace environment as to hedonic environment got a composite mean of 3.63 which is described as "agree/high". This composite mean relates to the fact that workplace environment such as hedonic environment is not very high and it is also not very low, low or moderate but it is high. Though it is not very high, the employees highly agree that the institution is a comfortable workplace. This evaluation is supported by each item when they are taken separately which all are rated within the same mean range level with the interpretation of "agree/high" such as "thanking the institution because it provides enough benefits (3.50), the work that one is doing is interesting (3.73), the transparency of rules in the institution is making the work easier (3.55), believing that the position in which one works is adequate to his/her skills (3.67), seldom encounter problems in the work (3.52), feeling satisfied with the work (3.71), feeling that the atmosphere at the work is welcoming and friendly (3.64), the company is a positive workplace (3.56), believing that one is liked and accepted at work (3.67) and feeling that the supervisors appreciate the work" (3.70).

Table 7: Workplace Environment as to Eudemonic Work Environment

\begin{tabular}{lcc}
\hline Eudemonic Work Environment & Mean & DR \\
\hline I. Autonomy Needs & 3.46 & $\mathrm{~A}$ \\
\hline 1. At work, I feel a sense of choice and freedom in the things I undertake. & 3.57 & $\mathrm{~A}$ \\
\hline 2. I feel that my decisions on my job reflect what I want. & 3.55 & $\mathrm{~A}$ \\
\hline 3. I feel my choices on my job express who really, I am. & 3.60 & $\mathrm{~A}$ \\
\hline 4. I feel I have been doing what interests me in my job. & $\mathbf{3 . 5 4}$ & $\mathbf{A}$ \\
\hline Composite mean & 3.74 & $\mathrm{~A}$ \\
\hline II. Relatedness Need & 3.77 & $\mathrm{~A}$ \\
\hline 1. I feel that the people I care at work about also care about me. & 3.75 & $\mathrm{~A}$ \\
\hline 2. I feel connected with people who care for me at work and for whom I care at work. & $\mathrm{A}$ \\
\hline 3. At work, I feel close and connected with other people who are important to me. & 3.77 \\
\hline 4. I experience a warm feeling with the people I spend time with at work. & $\mathbf{3 . 7 6}$ \\
\hline Composite mean & $\mathbf{A}$ \\
\hline III. Competence Need & 3.88 & $\mathrm{~A}$ \\
\hline 1. I feel confident that I can do things well on my job. & 3.87 & $\mathrm{~A}$ \\
\hline 2. At work, I feel capable of what I do. & 3.82 & $\mathrm{~A}$ \\
\hline 3. When I am at work, I feel competent to achieve my goals. & 3.83 & $\mathrm{~A}$ \\
\hline 4. In my job, I feel I can complete a difficult task. & $\mathbf{3 . 8 5}$ & $\mathbf{A}$ \\
\hline Composite mean & $\mathbf{3 . 7 2}$ & $\mathbf{A}$ \\
\hline Weighted Mean &
\end{tabular}

Source: Fox, Ryan, and Deci (2000)

Following the hedonic workplace environment is the eudemonic work environment. Based on the data presented in the table, it reveals that as a whole, the eudemonic work environment got a composite mean of 3.72 which is understood as "agree/high". This suggests that as a whole the work environment of the institution along with the eudemonic environment is not very high and it is also not very low, low or moderate but it is high. The result pointed out that the employees agree to a high extent that their autonomy, relatedness and competence needs are met or fulfilled. Even when they are taken separately, the three indicators got the same level 
composite mean with the interpretation of "agree/high" such as autonomy need (3.54), relatedness need (3.76) and competence need (3.85). The same result as we take into the items of the three indicators, they all got the same level of mean rating with the interpretation of "agree/high" such as "feeling a sense of choice and freedom in the things one undertakes (3.46), feeling that the decisions on the job reflect what one wants (3.57), feeling that the choices on the job express who really, I am (3.55), feeling that I have been doing what interests me in my job (3.60), feeling that the people I care at work about also care about me (3.74), feeling connected with people who care for me at work and for whom I care at work (3.77), feeling close and connected with other people who are important to me (3.75), experiencing a warm feeling with the people I spend time with at work (3.77), feeling confident that I can do things well on my job (3.88), feeling capable at what I do (3.87), feeling competent to achieve my goals (3.82) and feeling that I can complete the difficult task" (3.83).

Problem 4: Is there a relationship between organizational citizenship behaviour and work performance?

Table 8: Relationship between organizational citizenship behaviour and work performance

\begin{tabular}{lllll}
\hline & & Work Performance & & \multicolumn{1}{c}{$\begin{array}{l}\text { Counterproductive } \\
\text { work behaviour }\end{array}$} \\
\hline \multirow{2}{*}{ OCBO } & Task Performance & $\begin{array}{l}\text { Contextual } \\
\text { Performance }\end{array}$ & $\begin{array}{l}-.173^{*} \\
\end{array}$ \\
\cline { 2 - 5 } & Pearson Correlation & $.700^{* *}$ & $.716^{* *}$ & .020 \\
\cline { 2 - 5 } Sig. (2-tailed) & .000 & .000 & 181 \\
\hline $\mathrm{N}$ & 181 & 181 & $-.234^{* *}$ \\
\cline { 2 - 5 } & Pearson Correlation & $.691^{* *}$ & $.686^{* *}$ & .002 \\
\cline { 2 - 5 } & Sig. (2-tailed) & .000 & .000 & 181 \\
\hline
\end{tabular}

**. Correlation is significant at the 0.01 level (2-tailed).

*. Correlation is significant at the 0.05 level (2-tailed).

As indicated by the Pearson $\mathrm{r}$ correlation table 8, it displays that there is a significant correlation at 0.01 level (2-tailed) and 0.05 level (2-tailed) between organizational citizenship and work performance. Even when they are taken singly, it shows that organizational citizenship behaviour (OCBO) is correlated significantly at 0.01 level (2-tailed) with the task performance and contextual performance and it is also correlated significantly at 0.05 level (2-tailed) with the counterproductive work behaviour. It is also the same true with OCBP. There is a significant correlation between organizational citizenship behaviour (OCBP) at 0.01 level (2-tailed) and task performance, contextual performance and counterproductive work behaviour.

This result recommends that to improve work performance, the management must improve the organizational citizenship behaviour of the employees. Eliminating counterproductive work behaviour is a function of improving the organizational citizenship behaviour.

Problem 5: Is there a relationship between work environment and organizational citizenship and work performance?

Table 8. Relationship between work environment and organizational citizenship and work performance

Table 8: Relationship between Work Environment and Organizational Citizenship and work performance

\begin{tabular}{|c|c|c|c|c|c|c|}
\hline & & OCBO & OCBP & $\begin{array}{l}\text { Task } \\
\text { Performance }\end{array}$ & $\begin{array}{l}\text { Contextual } \\
\text { Performance }\end{array}$ & $\begin{array}{l}\text { Counter } \\
\text { productive work } \\
\text { behavior }\end{array}$ \\
\hline \multirow[t]{3}{*}{ HEDONIC } & Pearson Correlation & $.632^{* * *}$ & $.719^{* *}$ & $.537^{* *}$ & $.533^{* *}$ & -.105 \\
\hline & Sig. (2-tailed) & .000 & .000 & .000 & .000 & .158 \\
\hline & $\mathrm{N}$ & 181 & 181 & 181 & 181 & 181 \\
\hline \multirow[t]{3}{*}{ AUTONOMY } & Pearson Correlation & $.677^{* * *}$ & $.660^{* *}$ & $.810^{* *}$ & $.800^{* *}$ & $.286^{* *}$ \\
\hline & Sig. (2-tailed) & .000 & .000 & .000 & .000 & .000 \\
\hline & $\mathrm{N}$ & 181 & 181 & 181 & 181 & 181 \\
\hline \multirow[t]{3}{*}{ RELATEDNESS } & Pearson Correlation & $.626^{* *}$ & $.703^{* *}$ & $.575^{* *}$ & $.562^{* *}$ & $-.253^{* *}$ \\
\hline & Sig. (2-tailed) & .000 & .000 & .000 & .000 & .001 \\
\hline & $\mathrm{N}$ & 181 & 181 & 181 & 181 & 181 \\
\hline \multirow[t]{3}{*}{ COMPETENCE } & Pearson Correlation & $.551^{* *}$ & $.575^{* *}$ & $.513^{* *}$ & $.495^{* *}$ & $.457^{* *}$ \\
\hline & Sig. (2-tailed) & .000 & .000 & .000 & .000 & .000 \\
\hline & $\mathrm{N}$ & 181 & 181 & 181 & 181 & 181 \\
\hline
\end{tabular}

**. Correlation is significant at the 0.01 level (2-tailed).

*. Correlation is significant at the 0.05 level (2-tailed).

As indicated by the Pearson $\mathrm{r}$ correlation table 8 , it shows that there is a significant correlation between work environment and organizational citizenship behaviour and work performance at 0.01 level (2-tailed) and 0.05 level (2-tailed). The Pearson $r$ correlation reveals that hedonic workplace environment is significantly correlated with OCBO, OCBP, task performance, contextual performance and contextual performance but it has no significant correlation with counterproductive behaviour. The same is true with the eudemonic workplace environment. The Pearson $r$ correlation indicates that autonomy, relatedness and competence needs are significantly correlated with OCBO, OCBP, task performance, contextual performance and counterproductive work behaviour. 
This result suggests that to improve organizational citizenship and work performance of employees is to improve the workplace environment. The result also brings us further that hedonic is not correlated with counterproductive work behaviour but it has a significant correlation with autonomy, relatedness and competence needs. It means that the management must improve the autonomy, relatedness and competence needs to reduce or eliminate counterproductive work behaviour.

\section{Result and Discussion}

The result of this study found that there is a correlation between organizational citizenship behaviour and work performance specifically with the task and contextual performance but it does not have a correlation with counterproductive behaviour. This suggests that having a higher or better organizational citizenship behaviour is important to improve the task performance, contextual performance of employees and eliminate the counterproductive work behaviour. It was also found that there is a correlation between workplace environment and organizational citizenship behaviour and task performance. This finding indicates that improving organizational citizenship behaviour and task performance of employees is facilitated or mediated by the workplace environment. It means that organizational citizenship behaviour and work performance can only be improved if the issues of the workplace are also supportive for the growth of organizational citizenship behaviour and motivating employees' work performance. This finding is supportive of the previous study of Hafeez, et.al. (2019) that improving the workplace environment is important for work performance and the health of employees. Issues of the workplace are an important factor for management to manage because workplace issues are correlated to the counterproductive work behaviour of the employees. The current finding recognizes the importance of the hedonic and eudemonic workplace as a contributing factor to the psychological well-being of employees and a contributing factor to work performance (Grant \& McGhee, 2021).

The study found that organizational citizenship behaviour and workplace environment are correlated to counterproductive work behaviour. What does it imply? It just suggests that eliminating counterproductive work behaviour of employees is necessary to improve the organizational citizenship behaviour and work environment particularly along with eudemonic workplace environments such as autonomy needs, relatedness needs and competence needs. This result re-emphasizes the idea of Rothausen (2013) who argued that hedonic and eudemonic is related to well-being of employees because when the employees experience a hedonic and eudemonic work environment, they would be happy and can fulfil the goal of their job. His idea was built on the idea of Hobfoll (1989, p 8-9) on Conservation of Resources Theory. The Conservation of Resources Theory posits that the purpose of each person is to build resources that make their life fulfilling and enjoyable. When they have these resources, they experience positive wellbeing but when they do not have these resources, then they experience otherwise or negative well-being. There are two kinds of resources which are called primary and secondary resources (Griffin \& Clark, 2011). Secondary resources include the things that important to prevent the loss of the primary resources and primary resources include self-esteem, mastery, status, intimacy, and the protection and enhancement of the self (Hobfoll, 1989, cited by Rothausen, 2013). According to Rothausen (2013), the elements of primary resources are similar to those that comprise the psychological well-being and based on this idea, then hedonic and eudaimonic work environment is included in the primary resources that one has to attain or achieve. The elements of the eudaimonic work environment are the elements of psychological well-being. According to Ryan and Deci (2000), the elements of basic psychological well-being are autonomy, relatedness and competence needs. When these needs are met, employees experience positive well-being and when these needs are not met, then employees may experience negative well-being. Therefore, workplace environment such as hedonic and eudaimonic workplace environment needs to be given special attention by the management because according to some scholars such as Brief, (1998), Chatman, (1989), Dormann \& Zapf, (2001) that job-related attitudes are a function of the individual disposition, the environment or the match between the two aspects. Hedonic workplace environment refers to pleasure attainment and avoidance of pain (Kahneman, et.al, 1999) which indicate that the employees experience job satisfaction and positive emotion emanated from the workplace. While eudaimonic workplace environment is related to the meaning and the self-realization which may indicate the full functioning of the person (Ryan \& Deci, 2001). In other words, when the autonomy, relatedness and competence needs are met, the employees experience psychological well-being.

The finding of the current study broadens the discussion on the influence of organizational citizenship behaviour on work performance. Organizational citizenship may affect the work performance provided that the work environment is conducive for the organizational citizenship behaviour to flourish. Thus work performance is a function of both namely organizational citizenship behaviour and workplace environment such as hedonic and eudaimonic workplace environment. Therefore, solving work performance is not just a matter of improving the organizational citizenship behaviour of employees but it is also a function of the workplace environment. Therefore, a better approach to solving work performance problem is to solve organizational citizenship behaviour and workplace environment problems.

\section{Conclusion}

The purpose of the study was to find out the organizational citizenship behaviour of the employees and their work performance as mediated by workplace environment, and the correlation between organizational citizenship behaviour and work performance, and then the correlation between work environment and organizational citizenship behaviour and work performance. The study found that the organizational citizenship behaviour, work performance of employees and work environment is high. It was also found that organizational citizenship behaviour of employees is significantly correlated to work performance specifically task performance and 
contextual performance and counterproductive behaviour. Further, it was found that work environment is significantly correlated to organizational citizenship behaviour and with the elements of work performance such as task performance, contextual work performance and counterproductive behaviour.

The study concludes that organizational citizenship may not affect work performance if the work environment is not supportive or conducive for the organizational citizenship to develop. Therefore, to improve work performance, the work environment has to be improved. Thus, to solve work performance problems, the management needs to check the organizational citizenship and the work environment at the same time. The study contends that organizational citizenship behaviour is caused by a favourable working environment. When the employees find enjoyment in their work and their basic psychological needs such as autonomy, relatedness and competence needs are met, the employees can develop organizational citizenship behaviour and can improve their work performance. Improving the organizational citizenship behaviour and work environment is necessary to eliminate the counterproductive work behaviour of employees. Therefore, the hypothesis of the study, that there is a correlation between organizational citizenship behaviour and work performance, between work environment and organizational citizenship and work performance is accepted.

The study recognizes its limitation. The study limits its investigation only on the OCBO, OCBP, work performance and work environment and it involves the small population of the Divine Word Colleges in the Ilocos Region which may not represent the whole Divine Word Colleges in the Philippines. The results may change if a bigger population is involved and therefore, another study is important to include more population.

\section{References}

Adams, J.S. (1965). Inequity in social exchange. In L. Berkowitz (Ed.), Advances in Experimental Social Psychology (Vol. 2, pp. 267-299). San Diego, CA: Academic Press.

AIHR Digital. (2020). Organizational Citizenship Behavior: Benefits and 3 Best Practices. Retrieved from https://www.digitalhrtech.com.

Allen H. (2008). Using routinely collected data to augment the management of health and productivity loss. J Occup Environ Med. 50:615-632.

Baard, P.P., Deci, E.L. \& Ryan, R.M. (2006). Intrinsic Need Satisfaction: A Motivational Basis for Performance and Well-Being in Two Work Settings. Journal of Applied Social Psychology, 34(1), 2045-2068.

Basu, E., Pradhan, R.K. \& Tewari, H.R. (2017). Impact of organizational citizenship behaviour on job performance in Indian healthcare industries: The mediating role of social capital. International Journal of Productivity and Performance Management, 66 (6), 780-796. https://doi.org/10.1108/IJPPM-02-2016-0048

Bateman, T. S., \& Organ, D. W. (1983.). Job satisfaction and the good soldier: The relationship between affect and "citizenship." Academy of Management Journal, 26, 587-595. https://doi.org/10.2307/255908

Bergeron, D. (2007). The Potential Paradox of Organizational Citizenship Behavior: Good Citizens at What Cost? The Academy of Management Review, 32(4), 1078-1095. Retrieved from http://www.jstor.org/stable/20159357

Borman, W.C. (2004). The Concept of Organizational Citizenship. Current Directions in Psychological Science. 13(6):238-241. https://doi:10.1111/j.0963-7214.2004.00316.x

Borman W.C, Motowidlo S.J. (1993). Expanding the criterion domain to include elements of contextual performance. In: Schmitt N, Borman WC, eds. Personnel Selection in Organizations. San Francisco, CA: Jossey Bass; 71-98.

Brief, A.P. (1998). Attitudes In and Around Organizations. Thousand Oaks, CA: Sage.

Brown, S. P., \& Leigh, T. W. (1996). A new look at psychological climate and its relationship to job involvement, effort, and performance. Journal of Applied Psychology, 81(4), 358-368. https://doi.org/10.1037/0021-9010.81.4.358

Campbell J.P. (1990). Modelling the performance prediction problem in industrial and organizational psychology. In: Dunnette MD, Hough LM, eds. Handbook of Industrial and Organizational Psychology. Palo Alto, CA: Consulting Psychologists Press; 687-732.

Campbell C.H, Ford P., Rumsey M.G. (1990). Development of multiple job performance measures in a representative sample of jobs. Pers Psychol.43, 277-300.

Caroline, N., Uche, S. \& Oluwaseun, A. (2019). Journal of Education and Human Development 8(3). https://doi.org/10.15640/jehd.v8n3a11

Chatman, J.A. (1989). Improving interactional organizational research: a model of person-organization fit. Academy of Management Review, 14, 333-349.

Combs, L. Y., Hall, A. \& Ketchen, D. (2006). How Much Do High-Performance Work Practices Matter? A Meta-Analysis of their Effects on Organizational Performance. Personnel Psychology, 59(3), 501-528.

Dormann, C. \& Zapf, D. (2001). Job satisfaction: A meta-analysis of stabilities. Journal of Organizational Behavior, 22, 483-504.

Fay, D, \& Sonnentag, S. (2010). .A look back to move ahead: new directions for research on Proactive performance and other discretionary work behaviours. Appl Psychol an Int Rev. 59, 1-20.

Firmansah, M, A., Christiananta, B., \& Ellitan, L. (2014). The Effect of Organizational Citizenship Behavior (OCB), Total Quality Management (TQM), Technology Leadership and Service Quality on the Performance of Private Universities in Surabaya. Academic Research International, 5(2), 174-185 
Fleurbaey, M., \& Blanchet, D. (2013). Beyond GDP: Measuring welfare and assessing sustainability. Oxford: Oxford University Press

Frese, M. \& Fay, D. (2001). Personal initiative: An active performance concept for work in the 21st century. Research in Organizational Behavior, 23, 133-187. https://doi.org/10.1016/S0191-3085 (01)23005-6.

Garg, P., Rastogi, R., \& Kataria, A. (2013). Promoting Citizenship Behaviors in Workplace: The Relevance of Organizational Justice and Psychological Well-being of Employees. Jindal Journal of Business Research, 2(2), 67 84. https://doi.org/10.1177/2278682115593439

George, J.M., \& Brief, A.P. (1992). Feeling good-doing good: A conceptual analysis of the mood at work-organizational spontaneity relationship. Psychological Bulletin, 112, 310-329. Doi: 0033-2909/92

Grant P., McGhee P. (2021). Hedonic Versus (True) Eudaimonic Well-Being in Organizations. In: Dhiman S.K. (eds). The Palgrave Handbook of Workplace Well-Being. Camden: Palgrave Macmillan. https://doi.org/10.1007/978-3-030-300258_37

Griffin, M.A, Neal A., \& Parker, S. K. (1993). A new model of work role performance: Positive behaviour in uncertain and interdependent contexts. Acad Manag J. 50, 327-347.

Griffin, M.A., Neal, A., \& Parker, S.A. (2007). A New Model of Work Role Performance: Positive Behavior in Uncertain and Interdependent Contexts. Academy of Management Journal, 50(2), 327-347.

Griffin, M...\& Clark, S. (2011). Stress and well-being at work. In S. Zedeck (Ed.), APA Handbook of Industrial and Organizational Psychology, Volume 3, (pp. 359-398). Washington DC: American Psychological Association.

Hafeez, I, Yingjun, Z., Hafeez, S. \& Mansoor, R. (2019). Impact of Workplace Environment on Employee Performance: Mediating Role of Employee Health. Business Management and Education, 17(2), 173-193.

Hasani, K. Boroujerdi, S.S. \& Sheikhesmaeili, S. (2013). The effect of organizational citizenship behaviour on organizational commitment. Glob Bus Perspect (2013) 1:452-470 DOI 10.1007/s40196-013-0026-3.

Hazzi, O.A. (2018). Organizational Citizenship Behavior: A Holistic Review. New York: Springer

LePine, J., Newton, D. \& Kim, J.K. (2018). Organizational Citizenship Behaviors. Oxford Bibliographies. https://doi.org/ 10.1093/OBO/9780199846740-0091

Hobfoll, S.E. (1989). Conservation of resources: A new attempt at conceptualizing stress. American Psychologist, 44, 513-528.

Kahneman, D., Diener, E., and Schwarz, N. (eds). (1999). Well-Being: The Foundations of hedonic psychology. New York, NY: Russell Sage Foundation.

Koopmans, L., Bernards, C.M., Hildebrandt, V.H., Buuren, S., Beek, A.J., Van der, H.C.W. (2014). Improving the Individual Work Performance Questionnaires Using Rasch Analysis. Journal of Applied Measurement, 15(2), 160-175.

Lemmon, G., \& Wayne, S. J. (2015). Underlying Motives of Organizational Citizenship Behavior: Comparing Egoistic and Altruistic Motivations. Educational Researcher, 22(2), 3-14. https://doi.org/10.3102/0013189X030004003

LePine, J.A., Newton, D.W. \& Chamberline, M. (2018). A meta-analysis of empowerment and voice as transmitters of highperformance managerial practices to job performance. Journal of Organizational Behavior, 39(10), https://doi.org/10.1002/job.2295

Lomas, T. (2019). Positive Work: A Multidimensional Overview and Analysis of Work-Related Drivers of Wellbeing. International Journal of Applied Positive Psychology. https://doi.org/ 10.1007/s41042-019-00016-5

MacKenzie, S. B., Podsakoff, P. M., \& Fetter, R. (1993). The Impact of Organizational Citizenship Behavior on Evaluations of Salesperson Performance. Journal of Marketing, 57(1), 70-80. https://doi.org/10.1177/002224299305700105

McCombes, S. (2021). How to Write a Literature Review. Scribbr. Retrieved from https://www.scribbr.com.

Miao, R. T. \& Kim, H.G. (2009). The Impact of Organizational Citizenship Behavior on Team Effectiveness in China: The Moderating Role of Task Complexity. Paper Presented at International Conference on Computer Sciences and Convergence Information Technology (ICCIT), South Korea. Retrieved from https://ieeexplore.iee.org

Murphy K.R (1989). Dimensions of job performance. In: Dillon RF, Pellegrino JW, eds. Testing: Theoretical and Applied Perspectives. New York: Praeger, 218-247.

Netemeyer, R. G., Boles, J. S., McKee, D. O., \& McMurrian, R. (1997). An investigation into the antecedents of organizational citizenship behaviours in a personal selling context. The Journal of Marketing, 61, 85-98. https://doi.org/10.2307/1251791

Nielsen, T. M., Hrivnak, G. A., \& Shaw, M. (2009). Organizational Citizenship Behavior and Performance: A Meta-Analysis of Group-Level Research. Small-Group Research, 40(5), 555-577. https://doi.org/10.1177/1046496409339630

Newland, S.J. (2012). Organizational Citizenship Behavior- Individual or Organizational Citizenship Behavior Organization: Does the Underlying Motive Matter? Master Thesis. Western Kentucky University. Retrieved from https://digitalcommons.wku.edu

Ocampo, L., Acedillo, V., Bacunador, A.M., Balo, C.C., Lagdameo, Y.J. and Tupa, N.S. (2018). A historical review of the development of organizational citizenship behaviour (OCB) and its implications for the twenty-first century. Personnel Review, 47 (4), 821-862. https://doi.org/10.1108/PR-04-2017-0136

Organ, D. W. (1988). Organizational citizenship behaviour: the good soldier syndrome. (pp. 1-43). Lexington: Lexington Books

Organ, D.W. (2015). Organizational Citizenship in International Encyclopaedia of the Social \& Behavioral Sciences (Second Edition). Lexington: Lexington Books. 
Posdakoff, P.M. \& Mackenzie, S.B. (1994). Organizational Citizenship Behavior and Sales Unit Effectiveness. Journal of Marketing Research, 30, 361-363.

Reeves, J.P. (Ed.) (2019). Well-Being as a Multidimensional Concept. New Mexico: Lexington Books.

Renn R.W \& Fedor, D. B. (2001). Development and field test of a feedback-seeking, self-efficacy, and goal setting model of work performance. J Manag. 27, 563.

Rioux, S. M., \& Penner, L. A. (2001). The causes of organizational citizenship behaviour: a motivational analysis. Journal of Applied Psychology, 86, 1306-1314. https://doi.org/ 10.1037//0021-9010.86.6.1306

Rollins T. \& Fruge, M. (1992). Performance dimensions: competencies with a twist. Training. 29, 47-51.

Rothausen, T.J. (2013). Hedonic and Eudaimonic Job-Related Well-Bing: Enjoyment of Job and Fulfilment of Job Purpose. Working Paper: University of St. Thomas, Minnesota. Retrieved from https://ir.stthomas.edu/cgi/viewcontent.cgi?article=1000\&context=ocbmgmtwp

Rotundo M, \& Sackett P. R. (2002). The relative importance of task, citizenship, and counterproductive performance to global ratings of performance: a policy capturing approach. J Appl Psychol. 87, 66-80.

Ryan, R. M. \& Deci, E. L. (2000). Self-determination theory and the facilitation of intrinsic motivation, social development, and well-being. American Psychologist, 55, 68-78. http://dx.doi.org/10.1037//0003-066X.55.1.68

Ryan, R. M., and Deci, E. L. (2001). To be happy or to be self-fulfilled: a review of research on hedonic and eudaimonic wellbeing, in Annual Review of Psychology, Vol. 52, ed. S. Fiske. Palo Alto, CA: Annual Reviews, 141-166.

Stewart, J. \& Walsh, K. (1994) Performance measurement: When performance can never be finally defined. Public Money \& Management, 14(2), 45 49. https://doi.org/10.1080/09540969409387815

Titisari, P. (2016). Peranan Organizational Citizenship Behavior. Jakarta: Mitra Wacana Media

Van Horn, J. E., Taris, T. W., Schaufeli, W. B., \& Schreurs, P. G. (2004). The structure of occupational well-being: A study among Dutch teachers. Journal of Occupational and Organizational Psychology, 77(3), 365-375. https://doi.org/10.1348/0963179041752718

Viswesvaran C. \& Ones, D.S. (2000). Perspectives on models of job performance. Int JSelect Assessm. 8, 216-226.

Weikamp, J. G., \& Göritz, A. S. (2016). Organizational citizenship behaviour and job satisfaction: The impact of occupational future time perspective. Human Relations, 69(11), 2091-2115. https://doi.org/10.1177/0018726716633512

Wisecarver, M.M. Carpenter, T. D, \& Kilcullen R.N. (2007). Capturing interpersonal performance in a latent performance model. Milit Psychol. 19, 83-101.

Yaakobi E. \& Weisberg J (2020) Organizational Citizenship Behavior Predicts Quality, Creativity, and Efficiency Performance: The Roles of Occupational and Collective Efficacies. Front. Psychol. 11:758. https://doi.org/10.3389/fpsyg.2020.00758

Publisher's Note: SSBFNET stays neutral with regard to jurisdictional claims in published maps and institutional affiliations.

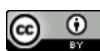

(C) 2021 by the authors. Licensee SSBFNET, Istanbul, Turkey. This article is an open access article distributed under the terms and conditions of the Creative Commons Attribution (CC BY) license (http://creativecommons.org/licenses/by/4.0/).

International Journal of Research in Business and Social Science (2147-4478) by SSBFNET is licensed under a Creative Commons Attribution 4.0 International License. 